\title{
Causes of glacier change in the source regions of the Yangtze and Yellow rivers on the Tibetan Plateau
}

\author{
YANG Jianping, DING YongJian, GHEN Rensheng, LIU Shiyin, LU Anxin \\ Cold and Arid Regions Environmental and Engineering Research Institute, Chinese Academy of Sciences, 260 Donggang West Road, \\ Lanzhou 730000, China \\ E-mail:jianping@ns.lzb.ac.cn
}

\begin{abstract}
Glaciers are an important element of the environment in the source regions of the Yangtze and Yellow rivers on the Tibetan Plateau. Using Geographical Information System techniques, we have studied changes in the location of glacier margins in two areas: the Geladandong area in the headwaters of the Yangtze, and the Anyêmaqên Shan mountains in the headwaters of the Yellow River. Marginal positions during the Little Ice Age (LIA) maximum, in 1969 in the Geladandong area, in 1966 in the Anyêmaqên Shan, and in 2000 in both areas, were determined using aerial photographs, satellite images, topographical maps and digital elevation models. Extrapolating the results to the entire source regions of the Yangtze and Yellow rivers, we estimate that the total glacierized area decreased about $1.7 \%$ between 1969 and 2000 in the Geladandong area and about $17 \%$ between 1966 and 2000 in the Anyêmaqên Shan. Glaciers were stable or advanced slightly between 1969 and 1995 in the Geladandong area, and between 1966 and 1981 in the A'nyêmaqên Shan, but have retreated since the mid-1990s in the former and since the 1980s in the latter. Significant increases in summer air temperature and decreases in annual precipitation are the causes of the present retreat. As a consequence of the retreat, water storage, as ice, in the Yangtze and Yellow river drainages is decreasing by $65-70 \times 10^{6} \mathrm{~m}^{3} \mathrm{a}^{-1}$.
\end{abstract}

\section{INTRODUCTION}

The past few decades have seen a temperature increase of $0.25^{\circ} \mathrm{C}$ per decade in parts of the Tibetan Plateau above $3500 \mathrm{~m}$ a.s.l. (Yao and others, 2000). Consequently, glaciers there, in the headwaters of the Yangtze and Yellow rivers, have retreated significantly (Wang, 1991; Ding and others, 1996; Ding and Bing, 1996). Because these glaciers are important to the eco-environment in these headwater drainages, their health has attracted widespread attention from both the scientific and the lay community, especially since the initiation of the West Development Project, a project to increase living standards in west China, and to decrease the difference in level of development between east and west China. Heretofore, however, there has been little detailed information about glacier fluctuations on the Plateau and their causes. In this paper we provide a comprehensive analysis of glacier change based on remote sensing, and explore the causes of this change using meteorological data.

\section{GLAGIER DISTRIBUTION AND GHARACTERIS- TICS IN THE STUDY AREA}

The source region of the Yangtze river, an area of $122 \times 10^{3} \mathrm{~km}^{2}$, is situated in the hinterland of the Tibetan Plateau. Based on data in the glacier inventory for the Yangtze drainage basin, in the headwaters of this region there are 753 glaciers with a total area of $1276 \mathrm{~km}^{2}$ and esti- mated total ice volume of $104 \mathrm{~km}^{3}$, accounting for $67 \%$ and $71 \%$ of the total area and volume of glaciers in the Yangtze river water system, respectively $(\mathrm{Pu}, 1994)$. Most of these glaciers are located on the northern slope of the Tanggula mountains, on the southern slope of the Kunlun Shan mountains, and on Sederi peak (Fig. 1). In the eastern part of this region, most of the glaciers are small, scattered cliff and cirque glaciers, while in the west they are larger valley and plateau glaciers. The snowline altitude increases from north to south and from east to west. The mean snowline altitude is $5345 \mathrm{~m}$ on the southern slope of the Kunlun Shan, and rises to $5533 \mathrm{~m}$ on the northern slope of the Tanggula mountains. Precipitation is $<300 \mathrm{~mm} \mathrm{a}^{-1}$ in the west, but $>400 \mathrm{~mm} \mathrm{a}^{-1}$ in the east. Mean annual air temperatures are -3.4 to $-5.0^{\circ} \mathrm{C}$ in the west. These low temperatures partially compensate for a lack of precipitation, so this combination of snow and temperature still favours the maintenance of glaciers in the west.

The source region of the Yellow River is on the eastern edge of the Tibetan Plateau, east of the Bayanaxar mountains (Fig. 1). Glaciers in this area are concentrated on the eastern slope of the A'nyêmaqên Shan. Here, there are 58 glaciers with a total area of about $125 \mathrm{~km}^{2}$, accounting for $96 \%$ and $98 \%$ of the total area and volume, respectively, of glaciers in the headwaters of the Yellow River (LIGG, 1992). The snowline altitude range is $4990-5190 \mathrm{~m}$. Precipitation in summer accounts for $56-62 \%$ of the annual precipitation and, in the A'nyêmaqên Shan, is affected by the Asian monsoon. The mean annual temperature near the snowline is estimated to be $-9.4^{\circ} \mathrm{C}$, while the mean summer 


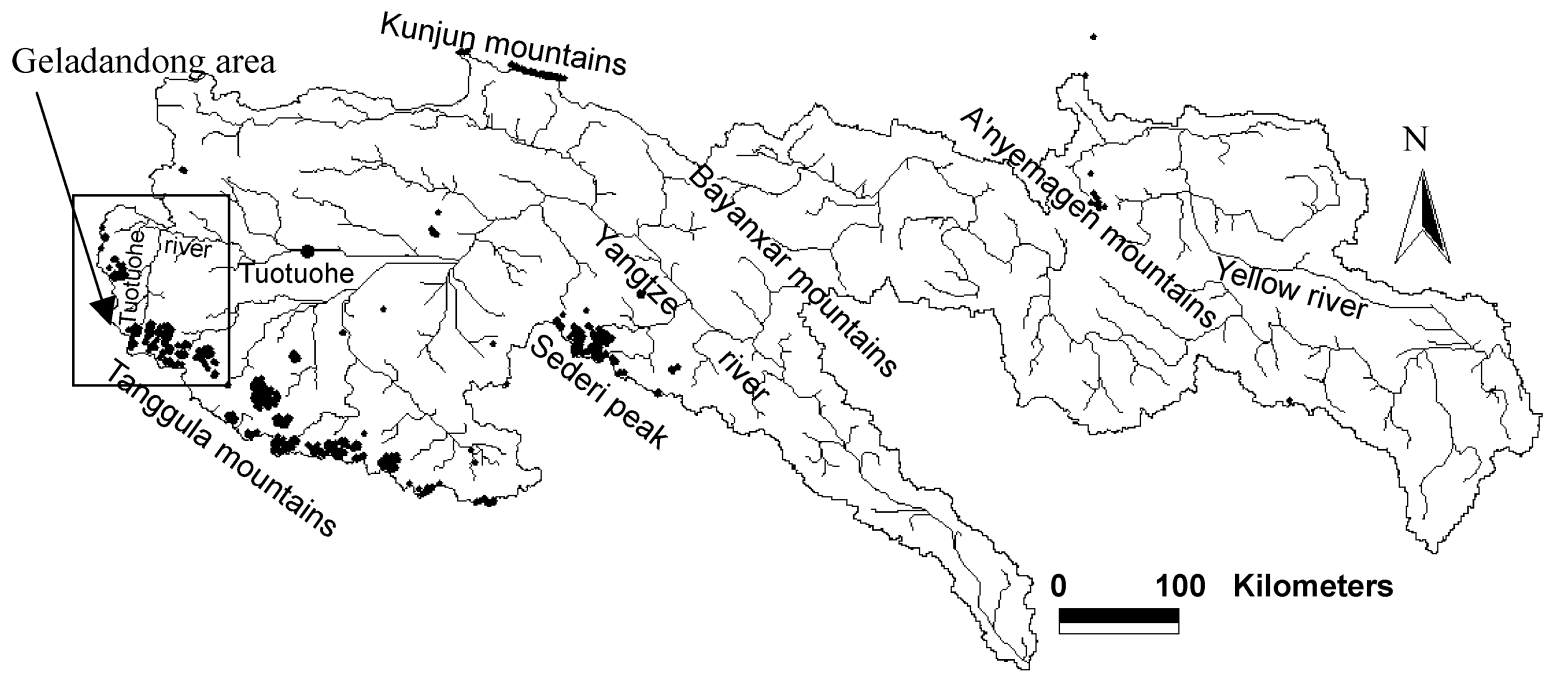

Fig. 1. Map showing distribution of glaciers in the source regions of the Yangtze and Yellow rivers and location of the Tuotuohe meteorological station.

temperature is $+2.2^{\circ} \mathrm{C}$. The mean annual precipitation in the Anyêmaqên Shan is $700-900 \mathrm{~mm} \mathrm{a}^{-1}$ (Liu and others, 2002). Table 1 shows the general formation of glaciers in the source regions of the Yangtze and Yellow rivers.

In each of these drainages, a representative area was selected for detailed study. These test areas are the Geladandong area in the Yangtze drainage, and the Anyêmaqên Shan in the Yellow River drainage.

\section{DESGRIPTION OF TEST AREAS AND DATA SOURGES}

\subsection{Geographical characteristics of the two test areas}

The Geladandong area is located in the Tuotuohe river catchment in the western part of the Yangtze drainage (Fig. 1). The area lies between $33^{\circ}$ and $33^{\circ} 40^{\prime} \mathrm{N}$ and $90^{\circ} 30^{\prime}$ and $91^{\circ} 31^{\prime} \mathrm{E}$. The altitude ranges from 5200 to $6621 \mathrm{~m}$. The Tuotuohe river is a major tributary of the Yangtze. Many large glaciers are found in this area (five are $>30 \mathrm{~km}^{2}$ in area), which is the principal glacierized area in the headwaters of the Yangtze.

The A'nyêmaqên Shan are a northwest-southeast range situated at the eastern end of the Kunlun Shan (Fig. 1). The range lies between $34^{\circ} 20^{\prime}$ and $35^{\circ} \mathrm{N}$ and $99^{\circ} 10^{\prime}$ and $100^{\circ} \mathrm{E}$. At $6282 \mathrm{~m}$ a.s.l., Maqinggangri is the highest peak in the range. The A'nyêmaqên Shan are the most important glacierized area in the source region of the Yellow River.

\subsection{Glacier data and methodology}

There are no field measurements on glaciers in the Geladandong area or the A'nyêmaqên Shan. Our database consisted of (1) 1:60000 aerial photographs from 1969 in the Geladandong area and from 1966 in the A'nyêmaqên Shan, (2) Thematic Mapper satellite images of the two areas from 2000, (3) 1:100 000 topographic maps and aerial photographs from 1976 in the Geladandong area and from 1971 in the A'nyêmaqên Shan area, and (4) digital elevation models (DEMs) of two areas derived from the latter maps. The 1969 and 1966 aerial photographs were scanned to generate digital images. Coordinates were then obtained from the maps for points visible on both the maps and the various images, and these coordinates were used to orthorectify the images. Between 15 and 20 ground-control points were selected from topographic maps and identified on each image. The root-mean-square error of an independent set of points was selected and used to assess the accuracy of co-registration. The mean error bars from co-registration of all images were $31-80 \mathrm{~m}$ in the $x$ direction and $40-120 \mathrm{~m}$ in the $y$ direction.

In mountainous terrain, as a result of the effect of topography on mountain glaciers, changes in solar altitude angle affect the accuracy of mapping of glacier boundaries. DEMs in the Geladandong and Anyêmaqên Shan areas are thus used to develop further topographic corrections for the digital images, in an iterative procedure, to improve the accuracy of these images. The details of glacier change, such as the velocities and boundaries at different times, were

Table 1. Basic information and volume change of glaciers in the source regions of the Yangtze and Yellow rivers

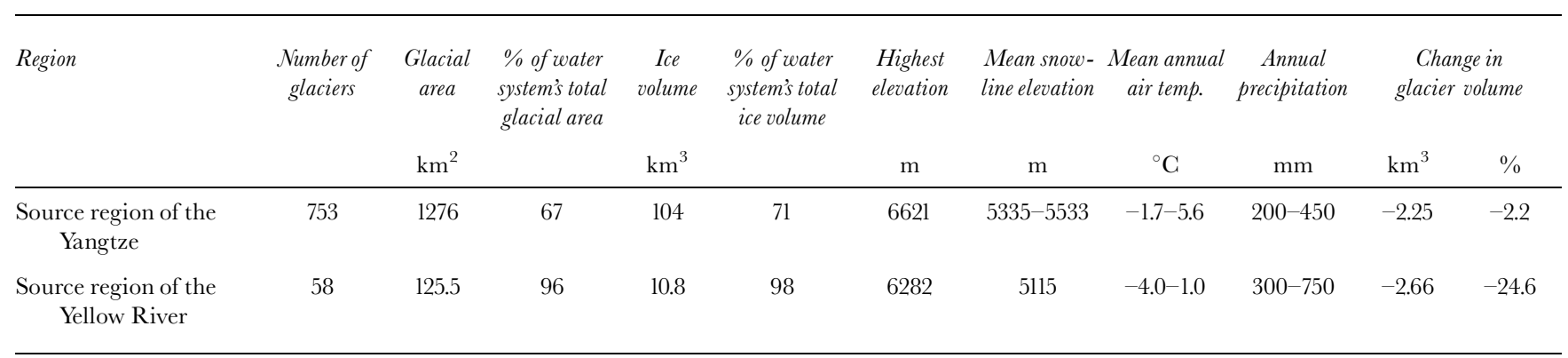



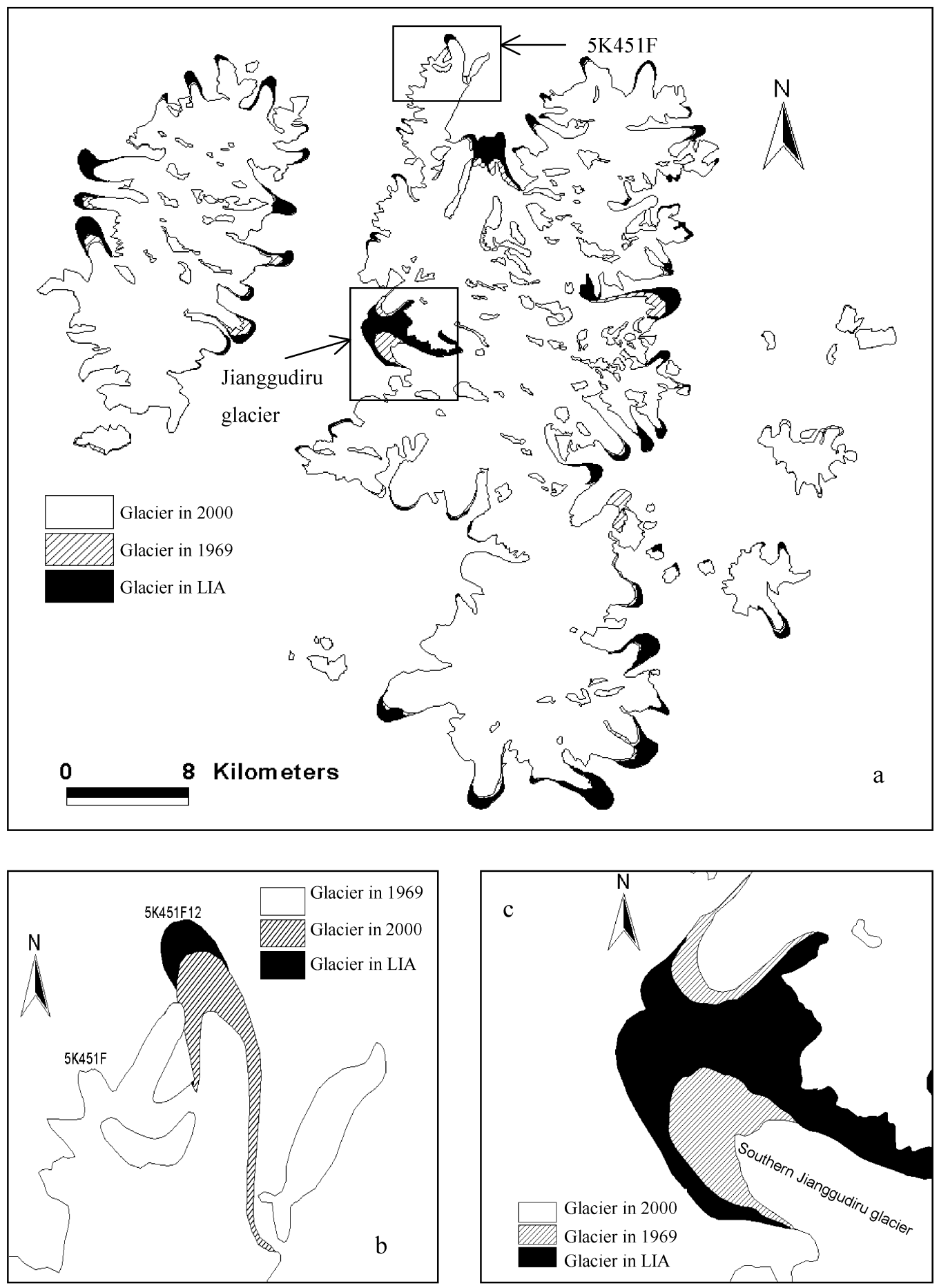

Fig. 2. Overlay map showing glaciers in the Geladandong area at the LIA maximum and in 1969 and 2000. Boxed areas in (a) show locations of glacier 5K451F12 (b) and southern Fianggudiru glacier (c).

Table 2. Changes in glacier area during the LIA and in 1966-69 and 2000 in typical glacierized areas of the source regions of the Yangtze and Yellow rivers

\begin{tabular}{|c|c|c|c|c|c|}
\hline \multirow[t]{2}{*}{ Area } & \multirow[t]{2}{*}{ Type of glaciers } & \multirow[t]{2}{*}{ Period } & \multirow{2}{*}{$\begin{array}{c}\text { Glacial area } \\
\mathrm{km}^{2}\end{array}$} & \multicolumn{2}{|c|}{ Change in area } \\
\hline & & & & $\mathrm{km}^{2}$ & $\%$ \\
\hline \multirow{4}{*}{ Geladandong area } & \multirow{3}{*}{ Polar-continental } & LIA maximum & 969.82 & & \\
\hline & & 1969 & 915.57 & -54.25 & -5.6 \\
\hline & & 2000 & 899.98 & -15.59 & -1.7 \\
\hline & \multirow{3}{*}{ Sub-continental } & LIA maximum & 147.8 & & \\
\hline \multirow[t]{2}{*}{ A'nyêmaqên Shan } & & 1966 & 125.5 & -22.3 & -15.1 \\
\hline & & 2000 & 103.8 & -21.7 & -17.3 \\
\hline
\end{tabular}


obtained by using Geographical Information System tools, based on the results of the serial images' co-registration, classification, vector analysis and calculation in these two areas. Glacier changes in the entire headwater areas of the Yangtze and Yellow rivers are inferred by extrapolation of these data.

\subsection{Meteorological data}

The location of the Tuotuohe meteorological station is shown in Figure 1. Tuotuohe is the only meteorological station in the headwaters of the Yangtze. It has operated continuously from the same location, yielding high-quality records, since it was set up in 1957. Owing to the lofty topography and cold climate in the headwaters of the Yangtze, seasonality is blurred. Air temperature drops below $0^{\circ} \mathrm{C}$ at the end of September each year, and rises above $0^{\circ} \mathrm{C}$ at the end of April or beginning of May the next year. Thus, precipitation falls as rain from May through September, accounting for about $92 \%$ of annual precipitation, and as snow from October to April. However, at the elevations of the accumulation areas of the glaciers in the headwater of the Tuotuohe river, we estimate that temperatures remain below $0^{\circ} \mathrm{C}$ for 8-9 months and that, even during warm periods, precipitation falls as snow because air temperature drops dramatically when precipitation occurs. However, snow falling on the ice surface in summer nearly always melts almost immediately. Therefore, in the discussion that follows we use data on changes in annual precipitation and in summer air temperature from the station as measures of changes at higher elevations affecting the glaciers.

\section{GLAGIER GHANGES IN THE LAST GENTURY}

\subsection{Change in glacierized area}

Glaciers in the Geladandong area have retreated during the last century. During the Little Ice Age (LIA) maximum, the total glacierized area was about $970 \mathrm{~km}^{2}$. By 1969, it had shrunk by $5.6 \%$, a mean rate of $0.02 \% \mathrm{a}^{-1}$. Between 1969 and 2000 it decreased by an additional $1.7 \%$, or $0.05 \% \mathrm{a}^{-1}$. Thus the mean annual shrinkage rate during the latter period is 2.5 times that from the LIA to 1969 (Table 2).

The total glacierized area in the Anyêmaqên Shan reached $148 \mathrm{~km}^{2}$ during the LIA maximum (Table 2). Since then it, too, has shrunk at an increasing rate. The mean shrinkage rate was $0.05 \% \mathrm{a}^{-1}$ from the LIA to 1966 , and about 10 times that, or $0.5 \% \mathrm{a}^{-1}$, between 1966 and 2000 . Glacier shrinkage in the Anyêmaqên Shan is much more severe than in the Geladandong area.

\subsection{Changes in glacier terminus positions}

Figure 2a shows the area covered by glaciers in the Geladandong area during the LIA, in 1969 and in 2000. Retreating glaciers far outnumber advancing ones. Of the retreating glaciers, southern Jianggudiru glacier has lost the most area (Fig. 2c); it retreated $1288 \mathrm{~m}$ between 1969 and 2000, a mean rate of $41.5 \mathrm{~m} \mathrm{a}^{-1}$. In contrast, glacier $5 \mathrm{~K} 451 \mathrm{~F} 12$, located in the northern part of the Geladandong area, advanced $680 \mathrm{~m}$, a rate of $21.9 \mathrm{~m} \mathrm{a}^{-1}$, during this same time period (Fig. 2b). The fact that the total glacierized area decreased only $1.7 \%$ and that there are some advancing glaciers suggests that glaciers in the Geladandong area are relatively stable. $\mathrm{m}$

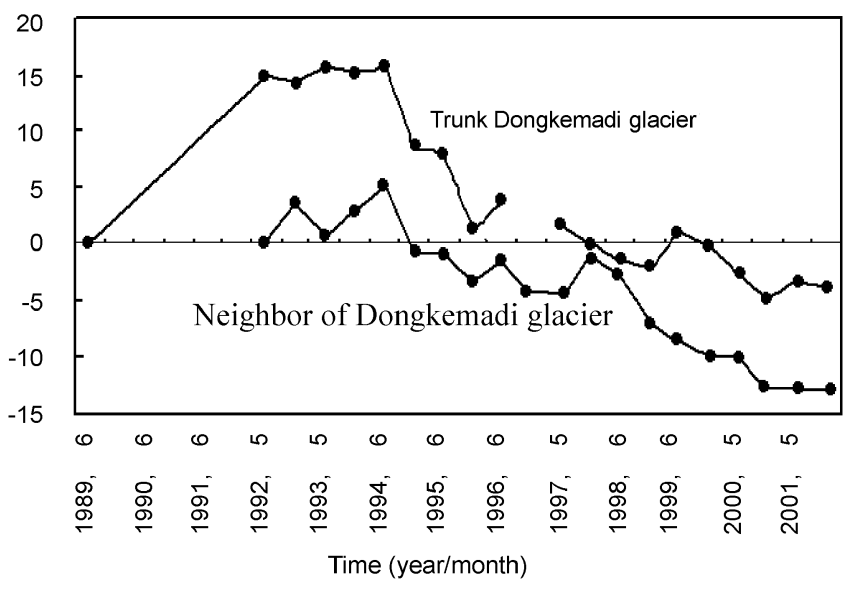

Fig. 3. Changes in the termini of the Dongkemadi glaciers.

Clearly, mean fluctuations over periods of several decades in the Geladandong area reveal only the general trend of glacier change in the headwaters of the Yangtze. Utilizing annual data on fluctuations of Dongkemadi glacier near Tanggula Pass, we can investigate the time series of changes in greater detail. The trunk Dongkemadi glacier and a neighboring glacier that merges with and then separates from Dongkemadi glacier advanced 9.4 and $2.1 \mathrm{~m}$, respectively, between 1969 and 1989 (Jiao and Yan, 1993). Longniyamaigangnalou and Longxiazailongba glaciers to the east and north of Dongkemadi glacier, respectively, were stable during this time. Thus, over a period of 20 years the termini of these four glaciers remained basically stable or advanced slightly. Then from 1989 to 1994, Dongkemadi glacier and its neighbor advanced $\sim 15$ and $5 \mathrm{~m}$, respectively (Fig. 3). Since 1994, both glaciers have been retreating steadily, but the retreat of Dongkemadi glacier has been relatively small. Thus, 1994-95 is a turning point: advancing glaciers dominated before 1995 and most glaciers have retreated since then.

Glaciers have a continuous recession trend since the mid-19th century on a global scale. However, the trend was interrupted by short intervals of stagnation or advance (Dyurgerov and Meier, 2000; Meier and others, 2003). Glaciers in most regions of the world advanced during the 1960s and 1970s, and in some places during the 1980s. Mountain glaciers in western Scandinavia advanced during the 1970s and 1980s (Bogen and others, 1989), in the Alps between the mid-1960s and the 1980s (Patzelt, 1985), in Alaska from the 1960s to the 1970s (Porter, 1986), in the Argentine Andes of the Southern Hemisphere during the 1970s and 1980s (Stingl and others, 1985; Leiva and others, 1986, 1989), and in North America over the period of the later 1960s to 1970s (Ding, 1995). Other mountain glaciers in western China also advanced slightly during this period (Zhang, 1981; Su and others, 1999). However, the period of continuous glacial advance in the headwaters of the Yangtze is longer than in other regions of the world. The observed longer period of glacial advance was found in other regions of the Tibetan Plateau, such as Bukatage peak located in the middle section of the Kunlun Shan. Most glaciers in northern Bukatage Peak advanced in the period 1976-94. For example, western Bukatage glacier advanced at a mean velocity of $58 \mathrm{~m} \mathrm{a}^{-1}$ from 1976 to 1994. The retreat speed of Bukatage glacier reduced largely in the same period ( $\mathrm{Li}$ and others, 


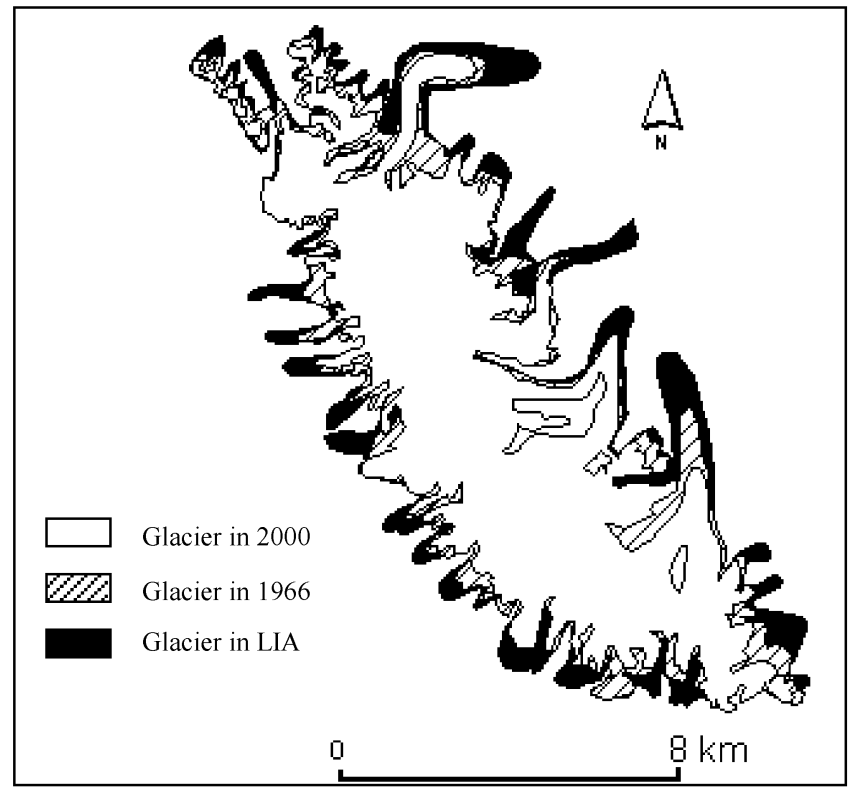

Fig. 4. Map showing extent of glaciers in A'nyêmaqên Shan at the LIA maximum and in 1966 and 2000.

1999). Thus, glacier change in the source region of the Yangtze and in other regions of the Tibetan Plateau is not only consistent with that worldwide, but also has characteristics unique to the hinterland of the Tibetan Plateau.

In Figure 4 we show boundaries of glaciers in the A'nyêmaqên Shan in the headwaters of the Yellow River during the LIA maximum and in 1966 and 2000. Measurements of length along the central flowlines of individual glaciers show that 53 retreated, 2 were stable and only 3 advanced between 1966 and 2000. Yehelong glacier retreated the furthest: $1950 \mathrm{~m}$ in 34 years, reducing its length by $23 \%$. The absolute length of retreat of small glaciers is less than that of larger ones, but the percentage retreat is normally quite large. For example, the relatively small glacier 5J352E13 lost $77 \%$ of its length between 1966 and 2000. Glacier retreat in the A'nyêmaqên Shan has accelerated recently. The annual retreat rate for last 34 years is over nine times the corresponding rate from the LIA maximum (taken as AD 1681, the mean between 1622 and 1740) to 1966. However, the lengths of some glaciers did not change significantly between the LIA maximum and 1966.

The phasing of glacier change in the Anyêmaqên Shan is similar to that of glaciers in the Geladandong area. Of 40 glaciers in the A'nyêmaqên Shan, 22 (55\%) were stable and 15 (37.5\%) advanced between 1966 and 1981 (Wang, 1987). Halong glacier had the largest advance: $790 \mathrm{~m}$ in 15 years, a mean rate of $52.7 \mathrm{~m} \mathrm{a}^{-1}$. Though Yehelong and Weigeledangxiaong glaciers were in retreat during this time, their retreat rates were relatively low: -10 and $14.7 \mathrm{~m} \mathrm{a}^{-1}$, respectively. Then, in the 1980s, glaciers began to retreat universally. In two decades, Halong and Yehelong glaciers retreated 406 and $1800 \mathrm{~m}$, respectively, or at mean rates of 20.3 and $90 \mathrm{~m} \mathrm{a}^{-1}$. Thus, for the most part, accelerated retreat of glaciers occurs after 1981 in the A'nyêmaqên Shan.

\subsection{Changes in glacier volume}

Expansion or shrinkage of glaciers results in changes in the amount of water stored as ice. In the Geladandong area, $70 \%$ of the glaciers drain to the Yangtze. These glaciers account for about half of the total glacierized area in the
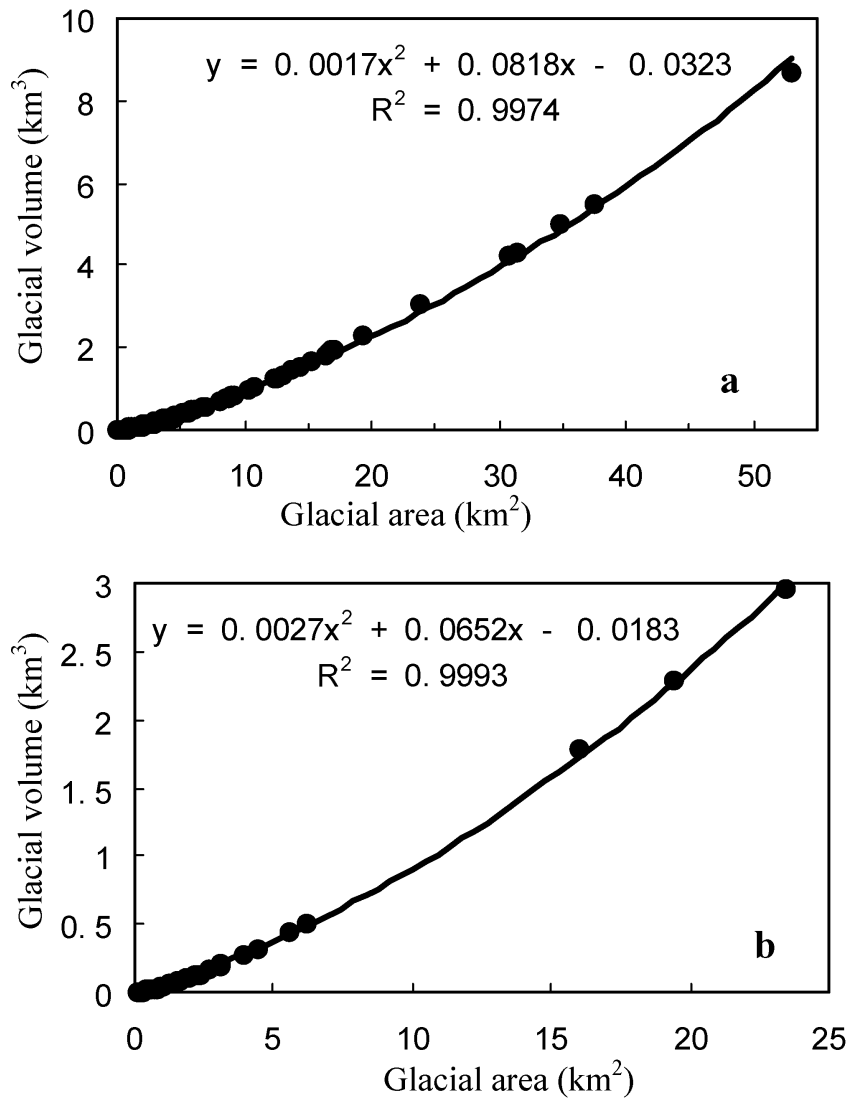

Fig. 5. Relation between glacier area and volume in the source regions of $(a)$ the Yangtze and $(b)$ the Yellow River.

source region of the Yangtze. Thus, glacial variations in the Geladandong area can be used to estimate the change in the entire source area of the Yangtze. Taking the $1.7 \%$ shrinkage in the last few decades in the Geladandong area as an estimate of the mean rate in the drainage, we find that the total area of glaciers in the drainage probably decreased $\sim 21.7 \mathrm{~km}^{2}$ between 1969 and 2000. Based on data in the glacier inventory for the Yangtze drainage basin ( $\mathrm{Pu}, 1994)$, the relation between glacier area and volume is as shown in Figure 5a. We can obtain the present area of each glacier that is shrinking by multiplying its area in 1969 by 0.983 $(=1.000-0.017)$. Then the present volume of each glacier can be obtained from the equation in Figure $5 \mathrm{a}$. Subtracting the volume thus calculated from that in 1969 and summing over all glaciers in the watershed yields an estimate of the decrease in glacier volume between 1969 and 2000 in the source region of the Yangtze. The total loss is $2.25 \mathrm{~km}^{3}$ of ice, or $2.03 \times 10^{9} \mathrm{~m}^{3}$ of glacier water. The annual loss rate is $\sim 65 \times 10^{6} \mathrm{~m}^{3} \mathrm{a}^{-1}$. Similarly, if the $17.3 \%$ decrease in glacier area in the Anyêmaqên Shan is taken as an estimate of the mean decrease in the source region of the Yellow River since 1966, the total is $\sim 22.74 \mathrm{~km}^{2}$, corresponding to a mean decrease in glacier volume of $2.66 \mathrm{~km}^{3}$ (Fig. 5b), and a loss of $2.39 \times 10^{9} \mathrm{~m}^{3}$ of water, an annual rate of $\sim 70 \times 10^{6} \mathrm{~m}^{3} \mathrm{a}^{-1}$.

In the course of estimating change in glacier volume in the entire source area of the Yangtze, the estimate is smaller than the actual value. The reason for the small estimated value is as follows. The climate is cold and glaciers are larger in the Geladandong area. Glacier change in this area is smaller than in other areas of the drainage. So, as shrinkage in the last few decades in the Geladandong area was taken as an estimate of the mean rate in the drainage, the estimated value is relatively small. For the source region of the Yellow 


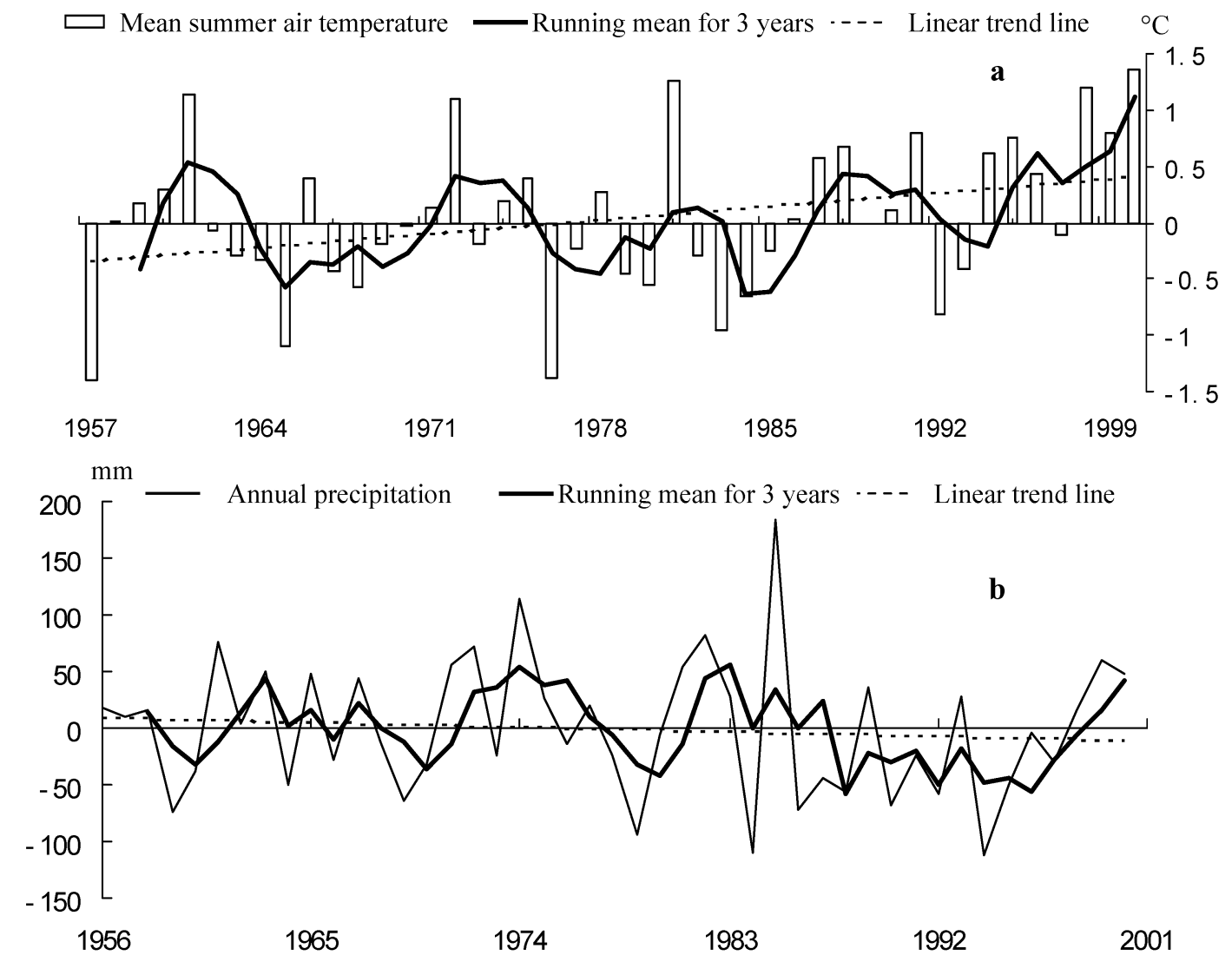

Fig. 6. Changes in mean summer air temperature (a) and mean annual precipitation ( $b$ ) in the Geladandong area.

River, the estimated value approaches the actual value. No available data or optimum method can be used to determine the specific estimated error up to now.

Our study of glacier fluctuations in the source regions of the Yangtze and Yellow rivers leads us to conclude that the amplitude of glacier change is far greater on the edges of the Tibetan Plateau, represented by the A'nyêmaqên Shan area, than in the hinterland of the Plateau represented by the Geladandong area. The mean shrinkage of the glacier area in the last few decades has been $17 \%$ in the former area and only $1.7 \%$ in the latter. Retreat rates of glacier termini reach $57.4 \mathrm{~m} \mathrm{a}^{-1}$ on the edge of the Plateau but only $41.5 \mathrm{~m}$ $\mathrm{a}^{-1}$ in the interior. In addition, the transition from advance to retreat occurs about 10 years earlier on the edges of the Plateau than in the hinterland. Indeed, the termini of some glaciers near Tanggula Pass were still advancing during the late 1980s and mid-1990s, whereas glaciers in the headwaters of the Yellow River started to retreat in the 1980s. Finally, the loss of glacial water reserves is far greater on the edges of the Plateau than in the hinterland. Although the total glacier area in the source region of the Yellow River is only $\sim 10 \%$ of that in the source region of the Yangtze, the total loss of glacial water reserves is $18 \%$ greater in the latter area.

\section{QUALITATIVE ANALYSIS OF THE GAUSES OF GLACIER CHANGE}

Using annual precipitation and summer temperature data from the Tuotuohe meteorological station over the past few decades, we next consider the causes of glacier change in the Geladandong area.
Tuotuohe meteorological station is situated somewhat east of the Geladandong area (Fig. 1), at an altitude of $4533 \mathrm{~m}$. The mean annual and mean summer air temperatures are $-4.2^{\circ}$ and $+6.5^{\circ} \mathrm{C}$, respectively, and the annual precipitation is $\sim 270 \mathrm{~mm} \mathrm{a}^{-1}$. Precipitation is normally in the form of rain between May and September, accounting for $\sim 92 \%$ of the annual precipitation. However, as noted earlier, at the elevations of the glacier accumulation areas we estimate that the period of $<0^{\circ} \mathrm{C}$ temperatures is 8 or 9 months long. Therefore, we assume that changes in mean summer temperature and in annual precipitation at the meteorological station are valid measures of the changes at higher elevations that affect glacier mass balance. Changes in mean summer air temperature and annual precipitation over the past four decades are shown in Figure 6.

Considering mean summer air temperature first, we see that temperatures lower than the long-term mean dominated between 1957 and 1986. Only $41 \%$ of these years' temperatures were above the mean, and, except for 1961, 1972 and 1981, temperatures that did exceed the mean were relatively small. Summers were cool in the Geladandong area during this period. In contrast, after $1986,80 \%$ of temperatures were above the mean. The mean summer temperature for these 15 years was $+6.9^{\circ} \mathrm{C}$, or $0.5^{\circ} \mathrm{C}$ higher than during the period 1957-86 and also $0.4^{\circ} \mathrm{C}$ higher than the longterm mean. Summer temperatures increased especially rapidly after the mid-1990s.

Globally, the 1950s to 1970 s was the second of two cool periods during the last century. While the global temperature decrease was $-0.13^{\circ} \mathrm{C}$, temperatures in China decreased $-0.63^{\circ} \mathrm{C}$ (Wang, 1990). Thus the temperature change in the Geladandong area is consistent with that in China as a whole and that in the world. The main difference 
is that the period of continuously low temperature was longer in the Geladandong area.

The trend in annual precipitation is in the opposite direction. Precipitation above the long-term mean occurred in $57 \%$ of the 30 years before 1986 , during which time mean annual precipitation was $285.6 \mathrm{~mm} \mathrm{a}^{-1}$, or $11.1 \mathrm{~mm} \mathrm{a}^{-1}$ higher than the long-term average $(274.5 \mathrm{~mm})$ and $33.3 \mathrm{~mm} \mathrm{a}^{-1}$ higher than in the 15 years after 1986 (Fig. 6b). Precipitation below the mean has occurred in 10 of the last 15 years. Thus, the period before 1986 was one of relatively high water input in the Geladandong area, and precipitation decreased significantly after 1986. Since 1998, however, precipitation has been increasing again.

Thus, from the 1950 s to the mid-1980s the climate in the Geladandong area was both wetter and cooler in summer. The combination of these two changes led to advances of some glaciers between the 1960s and the mid-1990s. The advances lagged the climatic change by $\sim 8$ years (Gao and others, 2000). After the mid-1980s, summer temperatures rose rapidly to their highest values in the last 50 years, while annual precipitation decreased significantly. The higher summer temperatures resulted in intense ablation, while the reduced precipitation produced less accumulation. Accordingly, glaciers retreated. The long-term trends are for an increase in summer temperature and a decrease in annual precipitation, suggesting that retreat may continue.

Although the long-term trend is for glacier retreat in the Geladandong area in the last century, some glaciers are still advancing. Whether increased precipitation at higher elevation, the distribution of the glaciated area with elevation, internal dynamics or some other cause leads to these advances, and whether these advances will continue, and if so for how long, cannot be determined with the data available. But monitoring data showed glacier advance in northern Bukagate peak resulted from increased precipitation in the mountainous area (Li and others, 1999).

\section{GONGLUSION AND DISGUSSION}

Glaciers on the Tibetan Plateau are an important component of mountain glaciers of the world, and changes in them contribute to the diversity of glacial change globally. In the last few hundred years, and especially the last 50 years, glaciers have changed in quite different ways in different parts of the Plateau. Glacier area decreased $\sim 1.7 \%$ between 1969 and 2000 in the Geladandong area in the headwaters of the Yangtze, and 17\% between 1966 and 2000 in the Anyêmaqên Shan in the headwaters of the Yellow River. The fastest rates of retreat were $41.5 \mathrm{~m} \mathrm{a}^{-1}$ in the Geladandong area and $57.4 \mathrm{~m} \mathrm{a}^{-1}$ in the A'nyêmaqên Shan. Compared with the Anyêmaqên Shan, the glaciers in the Geladandong area seem almost stable. Glaciers were relatively stable or advanced slightly between 1969 and 1995 in the Geladandong area and between 1966 and 1981 in the A'nyêmaqên Shan. They began to retreat universally after the mid-1990s in the Anyêmaqên Shan and after the 1980s in the Geladandong area. The transition from advance to retreat in the Geladandong area occurred about 10 years later than in the Anyêmaqên Shan. After a period of relatively high precipitation during the 1960s and 1970s, annual precipitation is decreasing in the Geladandong area, while summer temperature is increasing. This combination is the primary cause of glacial retreat.
Retreat of glaciers results in a decrease in glacier volume. The resulting losses in glacier water reserves are about $65 \times 10^{6} \mathrm{~m}^{3} \mathrm{a}^{-1}$ in the source region of the Yangtze and about $70 \times 10^{6} \mathrm{~m}^{3} \mathrm{a}^{-1}$ in the source region of the Yellow River over the last 30-35 years. Part of the decrease in glacier volume is due to evaporation directly into the atmosphere, but most of the decrease contributes to an increase in runoff of glacial meltwater. Based on changes in runoff during the rainy season in the Tuotuohe basin, runoff has probably increased slightly since the 1980s. Despite this increase, the present runoff still does not reach the discharge levels of the 1960s. Thus, glacier shrinkage is not having a particularly significant effect on runoff in the source region of the Yangtze.

\section{ACKNOWLEDGEMENTS}

The Project of Knowledge Innovation of the Chinese Academy of Sciences, NO. KZCX1-10-06 funded this work. The authors thank R. LeB. Hooke very much for revising our English and for giving us valuable advice. We are grateful to the Scientific Editor, J.W. Glen. We also thank H. Bjornsson and an anonymous reviewer for suggestions that significantly improved the paper.

\section{REFERENGES}

Bogen, J., B. Wold and G. Østrem. 1989. Historic glacier variations in Scandinavia. In Oerlemans, J., ed. Glacier fluctuations and climatic change. Dordrecht, etc., Kluwer Academic Publishers, 109-128.

Ding Yongjian. 1995. [Response of global glacier fluctuations to climatic change in recent 40 years.]. Science in China, Ser. B, 25(10), 1093-1098. [In Chinese.]

Ding Yongjian. 1996. [Comparative study of glacier fluctuations in China and Sweden.] 7. Glaciol. Geocryol., 18, Special issue, 96-104. (Cryosphere Vol. 2.) [In Chinese with English abstract.]

Ding Yongjian and Bing Hongtao. 1996. [Mass balance change of glaciers and its response to climatic change in recent 40 years.] 7. Glaciol. Geocryol., 18, Special issue, 23-32. (Cryosphere Vol. 2.) [In Chinese with English abstract.]

Dyurgerov, M. B. and M. F. Meier. 2000. Twentieth century climate change: evidence from small glaciers. Proc. Natl. Acad. Sci. U.S.A., 97(4), 1406-1411.

Gao Xiaoqing, Tang Maocang and Feng Song. 2000. [Discussion on the relation between glacial fluctuations and climate change.] [Plateau Meteorol.], 19(1), 9-16. [In Chinese with English abstract.]

Jiao Keqin and Yan Tianxiuer. 1993. [Glacier change in Kunlun Pass, Tanggula Pass and southeastern Tibet since last ice period.] In Shi Yafeng, ed. [Glacial Climate and Environment on the Qinghai-Tibetan Plateau]. Beijing, Science Press, 120-129. [In Chinese.]

Lanzhou Institute of Glaciology and Geocryology (LIGG). 1992. [Kunlun Mountains (drainage area of southern Qaidam basin and upper reaches of Yellow river).] In [Glacier inventory of China. Vol.VI]. Beijing, Science Press. Academia Sinica, Lanzhou Institute of Glaciology and Cryopedology, 1-105. [In Chinese.]

Leiva, J. C., G. Cabrera and L. E. Lenzano. 1986. Glacier mass balances in the Cajón del Rubio, Andes Centrales Argentinos. Cold Reg. Sci. Technol., 13(1), 83-90.

Leiva, J. C., L. E. Lenzano, G. A. Cabrera and J. A. Suarez. 1989. Variations of Rio Plomo glaciers, Andes Centrales Argentinos. In Oerlemans, J., ed. Glacier fluctuations and climatic change. Dordrecht, etc., Kluwer Academic Publishers, 143-151.

Liu Shiyin and 6 others. 2002. [Glacier fluctuations and inferred climate changes in the A'nyêmaqên mountains in the source area of the Yellow river.] F. Glaciol. Geocryol., 24(6), 701-707. [In Chinese with English abstract.]

Li Zhen, Sun Wenxin and Zeng Qunzhu. 1999. Deriving glacier change information on the Xizang (Tibetan) plateau by integrating RS and GIS techniques. Acta Geogr. Sinica, 54(3), 263-268.[In Chinese.]

Meier, M. F., M. B. Dyurgerov and G. J. McCabe. 2003. The health of glaciers: recent changes in glacier regime. Climatic Change, 59(1), 123-135.

Patzelt, G. 1985. The period of glacier advances in the Alps: 1965 to 1980. Z. Gletscherkd. Glazialgeol., 21, 403-407. 
Porter, S.C. 1986. Pattern and forcing of Northern Hemisphere glacier variations during the last millennium. Quat. Res., 26(1), 27-48.

$\mathrm{Pu}$ Jianchen. 1994. [The Changjiang (Yangtze) River drainage basin.]. In [Glacier inventory of China.Vol.VIII]. Beijing, Science Press. Academia Sinica, Lanzhou Institute of Glaciology and Cryopedology. [In Chinese.]

Stingl, H. and K. Garleff. 1985. Glacier variations and climate of the late Quaternary in the subtropical and mid-latitude Andes of Argentina. Z. Gletscherkd. Glazialgeol., 21, 225-228.

Su Zhen and others. 1999. Glacier fluctuations responding to climate change and forecast of its tendency over the Qinghai-Tibet Plateau. [Adv. Earth Sci.], 14(63), 607-612. [In Chinese with English abstract.]

Wang, S. 1990. Variations of temperature in China for the 100 year period in comparison with global temperature. Meteorology, 16(2), 11-15.

Wang Wenying. 1987. [Surveying of glacier variations in the northeastern part of Qinghai-Xizang Plateau.]. In Hövermann, J. and Wang Wenying, eds. [Reports on the northeastern part of the Qinghai-Xizang (Tibet) Plateau by Sino-W. German Scientific Expedition 7. Beijing, Science Press, 22-37. [In Chinese.]

Wang Zongtai. 1991. [Glaciers and environment in middle part of Tianshan and eastern part of Qilian since the Little Ice Age.] Acta Geogr. Sinica, 42(2), 160-167. [In Chinese.]

Yao Tandong, Liu Xiaodong and Wang Ninglian. 2000. [Question on the amplitude of climate change on the Tibetan Plateau.] [Chin. Sci. Bull.], 45(1), 98-106. [In Chinese.]

Zhang, X., B. Zheng and Z. Xie. 1981. [Recent variations of the existing glaciers on the Qinghai-Xizang plateau]. In Shi Yafeng, ed. Geological and ecological studies of Qinghai-Xizang plateau. Beijing, Science Press, 1625-1629. [In Chinese.]

MS received 6 June 2003 and accepted in revised form 18 September 2003 